Final Report as of Sept 30, 2005

\title{
HARVESTING A NEW WIND CROP: INNOVATIVE ECONOMIC APPROACHES FOR RURAL AMERICA
}

Prepared By:

Susan Innis

Green Power Marketing Director Western Resource Advocates 2260 Baseline Road, Suite 200 Boulder, CO 80302-7740

With Teaming Member:

Randy Udall

Director Community Office for Resource Efficiency

P.O. Box 9707

Aspen, CO 81612

For:

Department of Energy

Award No. DE-FG36-01SF22334

From August 31, 2001 to June 30, 2005

Project Officer - Keith Bennett 
DE-FG36-01SF22334

Western Resource Advocates

\author{
HARVESTING A NEW WIND CROP: \\ INNOVATIVE ECONOMIC APPROACHES \\ FOR RURAL AMERICA \\ By Susan Innis and Randy Udall
}

\title{
Executive Summary
}

This project, "Harvesting a New Wind Crop," helped stimulate wind development by rural electric cooperatives and municipal utilities in Colorado. To date most of the wind power development in the United States has been driven by large investor-owned utilities serving major metropolitan areas. To meet the 5\% by 2020 goal of the Wind Powering America program the 2,000 municipal and 900 rural electric cooperatives in the country must get involved in wind power development. Public power typically serves rural and suburban areas and can play a role in revitalizing communities by tapping into the economic development potential of wind power.

One barrier to the involvement of public power in wind development has been the perception that wind power is more expensive than other generation sources. This project focused on two ways to reduce the costs of wind power to make it more attractive to public power entities. The first way was to develop a revenue stream from the sale of green tags. By selling green tags to entities that voluntarily support wind power, rural coops and munis can effectively reduce their cost of wind power. Western Resource Advocates (WRA) and the Community Office for Resource Efficiency (CORE) worked with Lamar Light and Power and Arkansas River Power Authority to develop a strategy to use green tags to help finance their wind project. These utilities are now selling their green tags to Community Energy, Inc., an independent for-profit marketer who in turn sells the tags to consumers around Colorado. The Lamar tags allow the University of Colorado-Boulder, the City of Boulder, NREL and other businesses to support wind power development and make the claim that they are "windpowered." This urban-rural partnership is an important development for the state of Colorado rural communities get the economic benefits of wind power and urban businesses are able to claim the environmental benefits.

The second method to reduce the cost of wind power we investigated involved access to cheap capital. Municipal utilities and rural electric cooperatives have access to low-interest loan programs and frequently finance projects through the sale of revenue bonds, but we were interested in the possibility for small businesses and community banks to provide equity and debt for wind projects. We worked with Boulder Community Hospital to explore their interest in partnering with other businesses and individuals to help catalyze the first community-owned wind project in Colorado. We also met with and gained interest from the independent community banks for the idea of wind power. These small banks may be restricted by lending limits, but are an integral part of rural communities and are very interested in the economic development opportunities wind power presents for small towns.

This project was successful in getting six rural electric cooperatives and municipal utilities to purchase more than $25 \mathrm{MW}$ of wind power in Colorado, Wyoming and Nebraska. These utilities also announced plans to explore an additional $100 \mathrm{MW}$ or more 
DE-FG36-01SF22334

Western Resource Advocates

of wind power development over the next few years. Finally, munis and coops in New Mexico began exploring wind power by offering small green power programs to their customers. WRA believes the lessons learned from this project will assist other municipal utilities and rural electric cooperatives as they develop wind projects.

\section{Comparison of Accomplishments with Goals and Objects of the Project}

The project goal was to stimulate wind power development by Colorado's rural electric cooperatives and municipal utilities. Specifically, we wanted to spur the development of at least 3 new wind farms over the 2 year project period, using new financial tools and strategies for making small wind farms, in the 1 to $20 \mathrm{MW}$ range, more economically viable. We expected the new economic model would be replicated multiple times, yielding at least $50 \mathrm{MW}$ of new wind capacity in 5 years.

Specifically the project was designed to:

(1) Develop new economic tools, strategies and concepts for making small wind farms more economically viable. Such tools might include "green tags", low-cost capital, cooperative ownership, direct investment, and partnerships among public utilities, ski areas, and progressive businesses. These concepts would be bundled into a new, innovative, simple economic pro forma that could be replicated throughout rural America.

(2) Partnering with public utilities to build the first public-utility wind farm in Colorado. Initially we proposed to work with Lamar Light and Power, Arkansas River Power Authority, and Aspen Municipal Electric.

(3) Replicating the project in year two, by catalyzing small wind farms in adjoining states.

(4) Disseminating the lessons learned by publishing our results, findings, economic models, sample contracts for green tags, model legal agreements for small wind projects, financing documents and other such materials that would assist public power utilities and other stakeholders in duplicating our success.

\section{Accomplishments}

WRA and CORE were successful in our efforts to get municipal utilities and rural electric cooperatives to make additional wind power purchases. We helped catalyze the first municipally-owned wind project in Colorado, Lamar Light and Power and Arkansas River Power Authority's 7.5 MW wind farm. This project benefited economically from the development of an adjacent $162 \mathrm{MW}$ wind farm and from green tag sales to Community Energy, Inc. These are both strategies other public power entities can use to lower the cost of developing wind projects.

In addition to Lamar's project, several other municipal utilities and rural cooperatives increased their wind power purchases: Holy Cross Energy, Aspen Municipal, City of Glenwood Springs, Colorado Springs Utilities, Fort Collins Utilities. Details on each of these utilities are discussed in detail later in this report.

Getting utility management to commit to renewable energy required extensive outreach and education to bring staff and management up to speed on the benefits of wind energy. Many of the utility staff we met with had misconceptions about wind power 
and needed more accurate information on costs, benefits and technical issues with wind power. In many cases, rural electric cooperatives and municipal utilities faced restrictive contracts that prevented them from purchasing or generating renewable energy. We were limited in what we could do with these utilities and instead focused on several utilities in a position to purchase renewable energy.

We organized several meetings with the leadership of Tri-State Generation and Transmission and the Colorado Association of Municipal Utilities to encourage them to increase their renewable energy purchases and work with their members to bring economic development to rural Colorado through wind power development. We also met frequently with organizations in a position to influence utility leaders to embrace wind energy. Colorado's agricultural organizations, economic developers, and county commissioners frequently supported our efforts and engaged in their own strategies to influence rural electric cooperatives.

To build support for renewable energy among the members and customers of all public power utilities, we helped promote green pricing programs. Most utilities had programs in place, but were doing limited marketing. These programs usually result in very small renewable energy purchases by utilities, but they are useful in raising public awareness about wind power and allow consumers to demonstrate their commitment to renewable energy directly to their power provider. WRA has worked with several utilities throughout the Interior West who made significant wind power commitments as a result of strong customer participation in green power programs. For utilities with limited contracts, green power programs may be a good first step towards developing institutional support for wind power purchases.

As for innovative financing structures, WRA and CORE worked with Boulder Community Hospital and other businesses to explore the possibility of their direct investment in a wind power project. WRA worked with this "Quixote Wind" project to help them find resources (including a wind power developer and legal counsel) to move the project through the pre-development stages.

Finally, WRA found that in the competitive wind power industry it was difficult to obtain legal documents regarding ownership structures, financing models or contracts for green tags. Legal and financial documents or models are typically part of a preconstruction feasibility study specific to an individual project. For utility scale wind projects in the range of $20 \mathrm{MW}$ these feasibility studies (such as a cash flow analysis or pro forma, power curve analysis, documentation on turbine performance) can run close to \$1 million. This sort of detailed legal and economic analysis was far beyond the scope of this $\$ 120,000$ grant. For these reasons, we were unable to develop model financial documents, green tag contracts and other legal documents, beyond a very basic economic analysis done for Quixote Wind. This issue is further discussed in the summary of project activities -research section.

\section{Summary of Project Activities (August 2001 through June 2005)}

WRA and CORE's activities over the project period fell into three main categories: outreach and education; advocacy with individual utilities; and research into barriers, different approaches or new ownership models. Our activities for each 
DE-FG36-01SF22334

Western Resource Advocates

year are summarized below, including a discussion of the methods used and any deviations from our initial proposal.

\section{Outreach and Education}

WRA and CORE held meetings with national, state and local organizations who were in a position to help with this project. At the national level, we met with staff from the National Renewable Energy Lab, the Wind Powering America program, American Public Power Association, and the National Wind Coordinating Committee to solicit ideas and input on our project. At the regional and state level we met with the Western Area Power Administration, regional wholesale power suppliers including TriState Generation and Transmission and state-based utility associations like the Colorado Rural Electric Association and the Colorado Association of Municipal Utilities. We also had numerous meetings over the entire project period with individual rural electric cooperatives and municipal electric utilities. Finally, we met with organizations like the Rocky Mountain Farmers Union and Colorado Farm Bureau (representing landowners) and county commissioners interested in wind power development. In some cases, like with Wind Powering America, WRA and CORE solicited ideas on how to best approach coops and municipal utilities to engage their interest in developing a wind project. In other cases, for example with TriState G\&T, we were in the position of providing information and answering questions about wind power development to counter misunderstandings about the costs and benefits of wind power. In many cases we relied upon information from NREL and the DOE Wind Powering America program to provide accurate information about the benefits of wind power to utility officials.

In addition to many small group meetings, WRA and CORE helped organize and gave presentations at statewide wind power conferences in Colorado, New Mexico and Utah. Each of these conferences were well attended (300+ individuals at each) and provided valuable information to landowners, utility managers, county commissioners, agricultural community leaders, and other individuals and organizations interested in pursuing wind power projects. In Colorado, we followed up on the successful 2002 and 2004 Colorado Wind and Distributed Energy workshops by joining with the Colorado Governor's Office of Energy Management and Conservation and agricultural interest groups to present a series of workshops on wind power development to small groups around the state.

\section{Progress with Individual Utilities}

WRA and CORE worked with nine utilities in Colorado and New Mexico to convince them to purchase or generate wind power. These utilities included: Arkansas River Power Authority, City of Aspen municipal utility, Colorado Springs Utilities, Fort Collins Utilities, Glenwood Springs municipal utility, Holy Cross Energy, Kit Carson Electric, Lamar Light and Power, and Los Alamos County Utility.

\section{Arkansas River Power Authority and Lamar Light and Power}

CORE and WRA began exploring the possibility of a municipally-owned wind project with the Lamar municipal utility and their wholesale supplier ARPA in late 2001 (at that point Lamar had been collecting wind data for several months). Over the course 
of this project, CORE assisted Lamar Light and Power with several key steps including: resolving contractual issues with ARPA; assisting with wind data analysis and linking them with experts at the National Wind Technology Center, and helping Lamar develop an RFP for wind developer partners. Randy Udall met with the board of Arkansas River Power Authority to win their support for the project; he provided copies of the American Public Power Association's "Shades of Green" report on public preference for green power. Lamar hired the professional development company SeaWest to analyze data and perform a feasibility study for a $5 \mathrm{MW}$ project. WRA and CORE also discussed the possibly for Lamar to build their project in conjunction with GE Wind's $162 \mathrm{MW}$ project proposed for Gobbler's Knob, outside of Lamar.

The Lamar/ARPA project was commissioned in early 2004 and consists of 7.5 MW at two sites (four turbines are just south of Lamar and the fifth is in the town of Springfield). The project was paid for by $\$ 6$ million in revenue bonds issued by the Lamar Utilities Board, plus the sale of green tags to Community Energy, Inc., an independent for-profit green tag marketing company. The project realized some cost savings by piggybacking on the GE Wind project they used the same turbine supplier and construction company. We also believe working with a professional developer made the project successful and cost-effective.

\section{City of Aspen Electric}

CORE worked with the City of Aspen's utility to purchase 1.5 MW of wind from the Kimball, Nebraska wind project developed by the Municipal Energy Agency of Nebraska in 2002. This purchase brings Aspen's wind power use to about 7\% of its supply, making it one of the top utilities in the nation for the percentage of energy supplied by wind power. This project benefited from a unique financing concept -CORE helped finance the purchase with \$40,000 per year for 3 years from their Renewable Energy Mitigation Program. The Renewable Energy Mitigation Program was established in 2000 as a way to fund renewable energy and energy efficiency projects in Aspen and Pitkin County. The program is funded through a fee charged to new homeowners if their home exceeds the "energy budget" allotted to their property under the local building code.

\section{Colorado Springs Utilities}

WRA co-authored a white paper on clean energy options for the Colorado Springs municipal utility in 2003. One of our recommendations was for the utility to pursue at least $75 \mathrm{MW}$ of wind (about 5\% of their supply). The utility issued an RFP for $50 \mathrm{MW}$ of wind power in early 2004, but there has been little progress, presumably because the RFP was very inflexible in terms of location of a potential wind project and their treatment of a variable resource. WRA continued to support renewable energy in the City's Electric Integrated Resource Plan throughout 2004. We remain optimistic that Colorado Springs will increase their use of wind power, if for nothing else than to comply with the Colorado Renewable Energy Standard. The Renewable Energy Standard, passed as Amendment 37 in Fall 2004, requires the state's 7 largest utilities, including Colorado Springs, to obtain 10\% of their energy from renewable sources by 2015. 
DE-FG36-01SF22334

Western Resource Advocates

\section{Fort Collins Utilities}

WRA worked with the City of Fort Collins Utilities Department staff and local renewable energy advocates to launch a marketing push for the city's green power program in 2002. An increased awareness of renewable energy led to the City's adoption of the Electric Supply Policy in 2003. WRA provided technical advice to the team that wrote the supply policy. The policy calls for an increase in renewable energy from $2 \%$ in 2004 to $15 \%$ in 2017. As of 2004, Fort Collins had more than 1,000 residential customers and 75 businesses participating in their green power program, with wind power comprising about $2.3 \%$ of the municipal utility's supply. The utility purchases over 40,000 MWh of wind power and green tags from two projects in Wyoming.

\section{Glenwood Springs Municipal Utility}

The MEAN wind farm in Kimball, Nebraska supplies 1.5 MW of wind power to the Glenwood Springs municipal electric utility in Colorado, representing about 4\% of their electricity supply. This wind purchase is rate-based, meaning all customers share the costs and benefits. Glenwood is investigating additional wind power purchases.

\section{Holy Cross Energy}

CORE has worked for years to support the green power program offered by Holy Cross Energy. In 2001, Holy Cross agreed to make an additional 2 MW purchase of Colorado wind power from Xcel Energy for their Wind Power Pioneers program. In 2002 CORE worked with Holy Cross, Aspen Ski Company, ESPN and X Games to run all of Aspen's major events on wind power, including the first ever wind-powered World Cup race. Holy Cross has also expanded their commitment to renewable energy by agreeing to double their renewable energy purchases from $8 \%$ to $16 \%$ over next few years, in response to a customer survey that showed very strong support for renewable energy even with an increased cost. The utility currently buys about $5 \mathrm{MW}$ of wind power and has agreed to look into buying 20-40 MW of wind from a Colorado-based project when their existing supply contract expires. Holy Cross Energy's leadership on wind power earned them Wind Powering America's 2004 Rural Electric Utility of the Year award.

\section{Kit Carson Electric Cooperative}

WRA worked with Kit Carson Electric Coop in Taos, NM to develop marketing materials and a marketing strategy for their green power program. WRA and Kit Carson held a kickoff event in 2002 to launch the green power program. Since then the coop has investigated other ways to support renewable energy, given their contractual limitations on purchasing or generating wind power. They have recently been encouraging solar panel manufacturing in their area but remain open to the possibility of a wind project. 
DE-FG36-01SF22334

Western Resource Advocates

\section{Los Alamos County Department of Public Utilities}

At the request of advocates in New Mexico, WRA made a presentation to the Los Alamos municipal utility manager and staff, and interested local residents about renewable energy options for Los Alamos. WRA presented information on local ownership of renewables as well as green pricing programs. Los Alamos opted to offer residents a green pricing program beginning in 2005. The program is supplied by 200,000 $\mathrm{kWh}$ of renewable energy credits purchased through Public Service Co. of New Mexico from a $204 \mathrm{MW}$ wind project in House, NM.

\section{Research}

During the early stages of the project we reviewed literature on how previous cooperative and municipal utility wind projects were developed. In most cases the utility had a "champion" on board who thought wind power made sense and put a lot of effort into making the project happen. For example, Waverly Light and Power's wind project in Iowa was the result of impressive leadership by Glenn Cannon and a sizable grant from the American Public Power Association. These are two very important characteristics that are not present in many other utilities.

In terms of working with Colorado's public power utilities we spent some time learning more about the relationships between Colorado's public power utilities and their wholesale energy suppliers. More often than not we found that the coops and munis have limited options for pursuing wind power projects because of contractual agreements with their suppliers. For example, we learned of the "all-requirements" contracts between rural electric coops and TriState. These contracts prevent individual coops from providing more than 5\% of their own energy and also put stringent conditions on payments for lost revenues to the wholesale supplier. Most coops we spoke with felt these conditions made it economically risky for their coops to develop or purchase renewable energy without the cooperation of their supplier. In most cases the suppliers were not cooperative.

As we began to see significant barriers to coops and munis owning wind farms we decided to pursue existing paths to promoting wind power, like working with utilities with more flexible supply contracts or working to expand utility green power programs. In Colorado, twenty-five utilities offer customers the option to pay a little more a month to support the development of wind power. WRA discussed green power promotion with several utilities around the state. Many weren't interested in working with an environmental group on specific promotional campaigns, but all agreed to be listed on WRA's www.cogreenpower.org website. This site serves as a one-stop-shop for consumers interested in wind power in Colorado. Unfortunately Tri-State changed the supply mix of their green power program in 2004 and wind now accounts for less than $10 \%$ of the "green power" in their program (existing hydro and biomass make up the balance.) WRA also worked closely with utilities who were receptive to our assistance, specifically the City of Fort Collins (Colorado) municipal utility and Kit Carson Electric in Taos, New Mexico.

In terms of developing an innovative financial model, Randy Udall investigated how to replicate Samso, Denmark's wind power project. This small island built a $20 \mathrm{MW}$ offshore wind project in 2002, and financed it through the sale of \$500 shares to local 
residents. Unfortunately our research found that it would be nearly impossible to structure a wind power deal this way given the U.S. Securities and Exchange Commission regulations regarding investments by individuals. The legal work that would be required to satisfy the SEC regulations for individual investors to purchase small shares would be cost-prohibitive for a small project. We did explore exemptions from SEC regulations, including attracting money from a limited number of qualified investors or investors with an established relationship. We shared our research on these efforts with the Boulder Community Hospital's Quixote Wind project, which was investigating ways for the hospital and other small businesses to invest in a wind project in Colorado. We also developed for them a very basic financial model for a $20 \mathrm{MW}$ community-owned project developed in conjunction with a larger project. WRA also helped Quixote Wind find private consultants who could assist with economic analysis and ownership structure. Quixote Wind submitted a bid to Xcel Energy in partnership with PPM Energy to develop a wind project in southeastern Colorado. Xcel will announce the winners from that bid process in late 2005.

Most legal and economic analyses for wind developments are not publicly available. In this competitive industry, we found that very few successful projects were willing to share information without charging. Thus it was very difficult for us to research detailed information on ownership structure, financing arrangements or power purchase agreements from existing projects. It was also impossible for us to develop this information on our own given the size of the budget for this project. We did, however, come across several public documents and models that would be useful to munis and coops interested in wind power development. These publicly available resources are listed in Appendix B.

\section{Lessons Learned and Recommendations}

Of the nine utilities WRA and CORE worked with on this project, four have voluntary green pricing programs and five purchased wind power for their supply mix without charging customers a premium (in other words "rate-basing" their wind purchases). Utilities looking to acquire wind power can follow three successful tracks: (1) rate-basing wind power purchases, or

(2) rate-basing wind power purchases and selling green tags to third-parties, or (3) starting a voluntary green pricing program. For utilities choosing to rate-base wind power purchases, they may face a higher cost, but wind power will help insulate their customers from volatile fossil fuel costs and the risks of environmental regulations related to electricity production. Utilities that find wind power is too much of a premium cost on their system can help reduce the cost by selling green tags to third parties. In this case the utility wouldn't be able to make environmental claims about the wind project, but they would earn an added revenue source. Finally, if utilities are unwilling to pass costs of wind power through to all ratepayers they can opt to start a wind-based voluntary green power program. In this case they can become familiar with purchasing wind power and may opt to add rate-based wind at a later date (like Fort Collins Utilities).

If utilities face restrictive supply contracts they could explore offering a RECbased green power program, where they purchase green tags from a third-party and resell 
DE-FG36-01SF22334

Western Resource Advocates

them to their customer base. This has been a successful model in the northwest and could help finance a locally-owned wind project by providing an added revenue stream.

\section{Products Developed}

WRA and CORE developed several PowerPoint presentations for use in this work. A list of where these were presented is given in Appendix A.

WRA developed a list of useful resources for utilities interested in wind power development. These free, publicly available resources are listed in Appendix B.

WRA's white paper for the Colorado Springs Utility is included as Appendix C. We also refer to the Colorado Wind Power website, www.cogreenpower.org, which allows individuals throughout Colorado to learn more about wind power and green power options from their local utility. This website was not specifically developed for this project, but we did use it as a reference for people who were interested in more basic information about wind power or consumers interested in signing up for a green power program.

WRA and CORE did not develop any other products, technologies or databases for this project. 
DE-FG36-01SF22334

Western Resource Advocates

\section{Appendix A}

\section{Example List of Presentations, Conferences and Meetings Attended}

\section{1}

September 23-25 - Silver Creek, CO. Randy Udall gave a presentation on the benefits of wind power to the Colorado Rural Electric Association.

December 5-7 - Santa Fe, NM. National Wind Coordinating Committee meeting. Randy Udall and Susan Innis participated in discussions about how to encourage wind power development in New Mexico.

2002

January 19 - Grand Junction, CO. Western Colorado Congress Energy Workshop. Susan Innis gave a presentation about working with utilities and rural electric cooperatives on the Western Slope to develop wind power.

January 24-25 - Boulder, CO. University of Colorado Energy Conference. Susan Innis and Randy Udall gave presentations about wind power development in Colorado.

April 7-9 - Denver, CO. Colorado Wind and Distributed Energy Conference. Susan Innis presented about green marketing opportunities to support wind power and Randy Udall gave a keynote speech.

June 11 - Denver, CO. Sustainable Products Green Power Marketing Workshop. Susan Innis presented information on successful green power marketing. Attendees included Colorado Springs Utilities and Holy Cross Energy.

September 5 - Golden, CO. Wind Powering America strategy session. Susan Innis attended the annual wind program planning session at DOE and encouraged WPA to support community wind development activities.

September 9-11 - Montana Wind Power Workshop. Randy Udall was invited by Wind Powering America to participate in the workshop.

*September 18- Akron, CO. OEMC Rural Wind Workshop. Wes Perrin gave a presentation on economic development benefits of wind energy and green marketing techniques and benefits. Workshop attended by land owners interested in wind development, Washington County Commissioners, Economic Development director for Washington County, and Manager of Y-W Rural Electric Association.

October 19 - Montrose, CO. Delta Montrose Electric Association's Renewable Energy Fair. Wes Perrin gave a presentation on the economic development benefits of wind 
DE-FG36-01SF22334

Western Resource Advocates

energy and green marketing techniques and benefits. Fair was attended by Montrose and Delta County Commissioners, land owners, renewable energy advocates.

October 20-22 -Albuquerque, NM. New Mexico Wind Power Workshop. Susan

Innis and Randy Udall were invited by Wind Powering America to attend the workshop.

November 19 - Colorado Springs, CO. Wes Perrin met with the manager and board members of Holy Cross Electric and discussed economic development benefits of wind energy and green marketing issues.

December 4 - Denver, CO. Wes Perrin participated in a discussion of advancing small wind development on rural electric association distribution systems. Meeting was sponsored by ECO/ABB and NRECA.

December 6 - Ridgeway, CO. Wes Perrin met with the Southwest Renewable Energy Coalition. Wes participated in a discussion of the most appropriate methods to advance renewable energy in Southern Colorado, including community wind and green power marketing. The meeting was attended by the key accounts manager from San Miguel Power and renewable energy advocates.

December 12 - Golden, CO. Wes Perrin participated in an NREL meeting on rural issues and wind energy, including how to advance community wind in the West. The meeting was attended by NREL staff, landowners from around Colorado, Rocky Mountain Farmers Union members, and a representative of the American Corn Growers' Association.

\section{3}

January 10 - La Junta, CO. Wes Perrin gave a presentation on the economic development benefits of wind power and green marketing issues. The meeting was attended by the Otero County Economic Development agency, the Director of the Southeast Colorado Economic Development agency, Otero County Commissioners, and the President of Otero Junior College.

*January 11 - Kim, CO. Southern Colorado Livestock Association Meeting. Wes Perrin gave a presentation on the economic development benefits of wind to land owners, and board members and individual members of the Livestock Association.

February 23 - Gunnison, CO. Wes Perrin attended the annual meeting of the Gunnison County Electric Association.

March 7 - Lamar, CO. Wes Perrin spoke at the Rocky Mountain Farmers Union workshop on Renewable Energy Opportunities.

March 17 - Denver, CO. Wes Perrin attended the Colorado Rural Electric Association's Annual Meeting. 
DE-FG36-01SF22334

Western Resource Advocates

March 24 - Wes Perrin attended the 2003 Western United Electric Supply meeting.

April 2-3 - Golden, CO. Wes Perrin attended NREL/NRECA Wind Concept

Discussion, at the National Wind Technology Center.

April 14-15 - Westminster, CO. Susan Innis and Wes Perrin attended the

DOE/NRECA Wind Power Workshop at TriState G\&T.

April 21-22 -Austin, TX. National Wind Coordinating Committee meeting. Randy Udall was invited to speak about wind power in Colorado.

April 29-May 1 - Rosebud Sioux Reservation, SD. Randy Udall was invited to speak at the dedication ceremony for this tribal energy project.

May 14, 2003 - Wes Perrin met with Craig O'Hare, Special Assistant for Renewable

Energy, Governor Richardson's Office, re: New Mexico renewable energy strategy

May 19-22 - Wes Perrin attended the American Wind Energy Association's Annual Meeting.

June 27 - Steamboat Springs, CO. Colorado Bar Association Agricultural Law Conference. Susan Innis presented information about renewable energy issues in Colorado, including legal issues affecting rural communities and landowners interested in wind power development.

June 28 - Montrose, CO. Wes Perrin attended the Colorado Renewable Energy Society's Annual Conference.

August 7-8 - Wes Perrin spoke on rural economic development at the Southwest Renewable Energy Conference in Flagstaff, AZ

November 17 - Wes Perrin met with Tri-State G\&T, WAPA, NREL about deliberative polling of members to help inform decisions about renewable energy purchases.

November 18 - Colorado Springs, CO. Wes Perrin attended Colorado Conservation District's Annual Meeting.

November 19 - Lamar, CO. Wes Perrin attended meeting of Colorado Farm Bureau landowners interested in wind development.

December 2 - Colorado Springs, CO. Wes Perrin attended Colorado Counties, Inc. 2003 Southern District Annual Meeting.

2004

**February 26 - Los Alamos, NM. League of Women Voters of Los Alamos Public 
DE-FG36-01SF22334

Western Resource Advocates

Meeting on Energy Issues. Susan Innis gave a presentation on renewable energy options for the City of Los Alamos utility. Attendees included the manager and power purchaser for the municipal utility, representatives from the Los Alamos National Laboratory and concerned citizens.

June 23-24 - Minneapolis, MN. Susan Innis attended the Community Windpower conference sponsored by Windustry to network with other utilities and wind developers working on locally-owned wind projects.

\section{5}

February 4 - Boulder, CO. Colorado College Campus Sustainability Summit. Susan Innis gave a presentation on the renewable energy options for colleges, including green tags from $\mathrm{CO}$ wind projects.

February 8 - Boulder, CO. Boulder County Clean Air Consortium monthly meeting. Susan Innis spoke about wind power investment opportunities and the Boulder Community Hospital's investigation into wind farm ownership.

March 11 - Meeting with City of Boulder officials on wind power ownership.

March 11 - Colorado Renewable Energy Forum meeting, discussion of communityowned wind projects and opportunities with munis and coops.

May 12 - Burlington, CO. Meeting on community wind power and the City of Burlington utility's investigation into wind power.

May 17 - Denver, CO. Community wind power strategy session at Windpower '05 conference.

May 19 - Evergreen, CO. Wind Powering America state stakeholder summit.

June 10-11 - Fort Collins, CO. Colorado Renewable Energy Conference. Susan Innis spoke about green power options in Colorado, including green tags from municipal wind projects in Colorado.

June 13-14 - Evanston, WY. Institutes for Journalism and Natural Resources. Susan Innis and Randy Udall met with journalists from the region for a tour of the Spring Valley wind project and discussions of wind power development in Colorado and Wyoming.

* Expenses for participating in these events were covered by the Colorado Governor's Office of Energy Management and Conservation.

** Expenses for participating in these events were covered by WRA's core funding from the Energy Foundation. 
DE-FG36-01SF22334

Western Resource Advocates

\title{
Appendix B
}

\section{Free Resources for Utilities Interested in Wind Power Development}

\author{
Windustry \\ Wind Project Calculator -basic spreadsheet to help analyze the economics of \\ a wind project \\ (http://windustry.org/calculator/default.htm) \\ Presentations from the Community Windpower Conference, June 2004 \\ many useful presentations on financing wind projects, economics, lease \\ agreements, etc. \\ (http://windustry.org/conferences/june2004/default.htm)
}

\section{Environmental Law and Policy Center}

Community Wind Financing Handbook

(http://www.elpc.org/energy/windhandbook2004.pdf)

\section{Energy Trust of Oregon}

A Comparative Analysis of Community Wind Power Development Options for Oregon (http://www.energytrust.org/RR/wind/OR_Community_Wind_Report.pdf)

\section{Focus On Energy}

Wisconsin Community Based Wind Power Project Summary (http://www.focusonenergy.com/data/common/pageBuilderFiles/CW\%20Report\% 20Summary\% 20-\%20final2_317506509.pdf)

\section{The Minnesota Project}

Equity Capital for Community Wind Projects

(http://www.cleanenergyresourceteams.org/pdf/Equity\%20Capital.pdf)

\section{National Renewable Energy Lab}

Wind Finance -a calculator for analyzing the economics of a wind project (http://analysis.nrel.gov/windfinance/login.asp) 
DE-FG36-01SF22334

Western Resource Advocates

\section{Lawrence Berkeley National Lab}

A Comparative Analysis of Business Structures Suitable for Farmer-Owned Wind Power Projects in the United States (Report No. LBNL-56703 at http://eetd.lbl.gov/EA/EMP)

\section{National Wind Coordinating Committee}

Several publications on the economic development benefits of wind power, including how to calculate the benefits and case studies of the benefits of actual projects. (http://www.nationalwind.org/publications/economic_development.htm)

Note: websites accessed as of September 19, 2005 